\title{
PENGARUH PERUBAHAN SUDUT GANTRY TERHADAP NOISE PADA PEMERIKSAAN CT SCAN DENGAN TEKNIK SEQUENCE
}

\author{
Afif Akhsani ${ }^{1)}$, Luthfi Rusyadi ${ }^{2)}$, Fatimah ${ }^{3)}$ \\ 1), RSUD Dr. M. Ashari Kabupaten Pemalang \\ ${ }^{2), 3)}$ Jurusan Teknik Radiodiagnostik dan Radioterapi Poltekkes Kemenkes Semarang
}

e-mail : luthfirusyadi@yahoo.com

\begin{abstract}
Background: Noise is a fluctuation in the value of CT number and Standard Deviation which is one parameter in the assessment of CT Scan image quality. This study aims to see the effect of changes in the angle of the gantry on noise and conformity with the BAPETEN standard of the value of the CT Number and Standard Deviation fluctuations produced.

Methods: This type of research is quantitative with an experimental approach. The research subjects used water phantom to assess the value of CT Number and Standard Deviation by placing ROI on the resulting image. The SPSS test is used to see the relationship between changes in noise and noise. CT Number, Uniformity and Noise Uniformity tests are performed to assess CT Number and Standard Deviation in accordance with BAPETEN regulations.

Results: An increase in noise is indicated by fluctuations in the value of CT Number and Standard Deviation resulting from the placement of the ROI at the center of each image produced by each change in the angle of the gantry. The average value of CT Number at the gantry angle $0^{0}(-1.43), 5^{0}(-1.48), 10^{0}(-1.47), 15^{0}(-1.58), 20^{0}(-$ $1.62), 25^{0}(-1.68), 30^{0}(-1.7)$. The average value of the Standard Deviation at the $0^{0}$ gantry angle $(2.36), 5^{0}(2.35)$, $10^{0}(2,3), 15^{0}(2,33), 20^{0}(2,42), 25^{0}(2,57), 30^{\circ}(2.62)$. There is a significant relationship to the Pearson correlation test between changes in gantry angle and CT Number and Standard Deviation values. CT Number, Uniformity, and Noise Uniformity Test results were used to assess the fluctuations of CT Number and Standard Deviation due to changes in the angle of the gantry in accordance with the standard BAPETEN No. 2 of 2018 on all changes in the $0^{0}$ gantry angle to $-30^{\circ}$ with a range of $5^{0}$.

Conclution:. Noise fluctuations are caused by changes in the thickness of the scanning area object from changes in the gantry angle. The greater the change in angle of the gantry, the greater the thickness of the scanning area object. Changing the gantry angle causes the scanning area to change from the circle to the ellipse.
\end{abstract}

Keywords: noise, CT Number, gantry angle, CT Scan.

\section{Pendahuluan}

Lima karekteristik yang penting dalam pencitraan gambaran CT Scan, yaitu spatial resolution, contrast resolution, noise, distortion dan artefact $C T$ Scan. Noise merupakan perbedaan/variasi dari nilai HU pada suatu material yang sama sehingga dapat untuk membedakan koefisien atenuasi pada jaringan normal dan patologi. Namun nilai noise yang terlalu besar akan mengganggu resolusi kontras dari gambaran CT Scan yang akhirnya akan mempengaruhi hasil diagnosa, selain itu juga radiolog sering menggunakan ROI dalam pengukuran tissue/jaringan tertentu untuk menentukan hasil diagnosa (Kurniawan A.N. dan Soesanti I., 2010).

Noise merupakan fluktuasi nilai $C T$ number dan merupakan salah satu parameter dalam penilaian kualitas gambar CT Scan. Semakin rendah index image noise, maka kualitas gambar yang dihasilkan pada $C T$ Scan akan semakin baik. Semakin tinggi index image noise maka dapat dikatakan bahwa kualitas gambar $C T$ Scan akan semakin menurun, nilai noise yang terlalu besar akan menimbulkan artefak yang dapat mengganggu resolusi kontras dari gambaran CT Scan yang akhirnya akan mempengaruhi hasil diagnosis (Seeram E., 2009).

Noise pada gambaran CT Scan bisa diketahui dengan uji cross field uniformity CT number. Uniformity $C T$ number dapat diartikan sebagai nilai keseragaman $C T$ number air pada sebuah image noise. Pengukuran noise dilakukan dengan melakukan scanning pada water phantom berdiameter $20 \mathrm{~cm}$, kemudian dilakukan ROI pada daerah tepi dan pusat (Mas'uul A.R, dan Susanto H, 2014).

Menurut Peraturan Badan Pengawas Tenaga Nuklir (BAPETEN) Republik Indonesia Nomor 2 Tahun 2018 tentang uji kesesuaian pesawat sinar-X radiologi diagnostik dan intervensional, bahwa standar keseragaman noise (Standard deviasi) nilai CT number air pada pengujian menggunakan water phantom adalah $\leq 2 \mathrm{HU}$, dengan nilai rata-rata ROI pusat $-4 \leq C T$ number $\leq 4$ dan nilai maksimum dari selisih ROI ratarata di pusat dengan ROI rata-rata di tepi-tepinya adalah $2 \mathrm{HU}$ pada $120 \mathrm{kVp}, 300 \mathrm{mAs}$, dan slice thicknes $8 \mathrm{~mm}$. Ini menunjukan bahwa standar deviasi (SD) ROI di atas rentang tersebut dapat didefinisikan sebagai noise. 
Menurut Seeram (2009) terdapat tiga faktor utama yang mempengaruhi noise pada citra. Faktor pertama adalah noise kuantum yang ditentukan oleh fluktuasi sinar-X atau jumlah foton sinar-X yang terdeteksi. Hal ini dipengaruhi oleh teknik scanning (tegangan tabung, arus tabung, slice thickness, kecepatan scanning, dan pitch helical). Faktor yang kedua adalah efisiensi scanning (misalnya, efisiensi detektor kuantum, efisiensi geometri detektor, rasio amber-penumbra), dan faktor yang ketiga pasien (ukuran pasien, jumlah tulang dan jaringan lunak pada bidang pemindaian). Selain ketiga faktor tersebut, menurut Hoppe (2013) pada jurnal yang diterbitkan oleh American Assosiation of Physicists in Medicine, dengan perlakuan perubahan sudut gantry $0^{\circ}$ sampai dengan $30^{\circ}$ pada rentang $5^{0}$ akan meningkatkan $2 \%$ - $50 \%$ noise standar deviasi. Demikian juga pada penelitian yang dilakukan oleh Nikupaavo (2015) pada jurnal yang diterbitkan oleh AJR menunjukkan bahwa kemiringan sudut gantry dapat meningkatkan noise yang di hasilkan sebesar $30 \%$ pada citra yang dihasilkan.

Berdasarkan latar belakang tersebut, peneliti akan melakukan penelitian menggunakan water phantom dengan merubah sudut gantry dari $0^{0}$ sampai $30^{\circ}$ dengan rentang $5^{0}$ untuk setiap scanning. Perubahan sudut gantry diharapkan akan terjadi fluktuasi nilai $C T$ Number pada citra yang menunjukkan ada tidaknya noise pada citra yang dihasilkan.

\section{Metode}

Jenis penelitian ini adalah penelitian kuantitatif dengan pendekatan eksperimental. Lokasi penelitian dilakukan di Instalasi Radiologi RSUD Dr. M. Ashari Kab. Pemalang.

Subjek penelitian menggunakan water phantom yang digunakan untuk mengukur noise di lihat dari nilai CT Number dan Standard Deviasi CT number pada citra yang dihasilkan pada perubahan sudut gantry $0^{0},-5^{0}$, $10^{0},-15^{0},-20^{0},-25^{0},-30^{\circ}$, pada pesawat MSCT Siemens Somatom 16 slice. Pemilihan perubahan sudut gantry merujuk pada penelitian sebelumnya yang dilakukan oleh Hoppe (2013) dengan variasi perubahan sudut $0^{0}$ $\mathrm{s} / \mathrm{d}-30^{\circ}$ pada rentang perubahan setiap $5^{0}$.

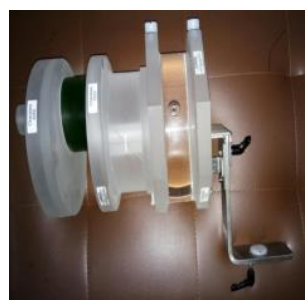

A

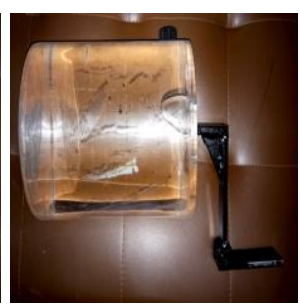

B
Gambar 1. Water phantom siemens (A) water phantom buatan (B)

Water phantom buatan digunakan karena keterbatasan panjang water phantom siemens yang akan mengakibatkan terpotongnya area scanning apabila dilakukan pengujian dengan penyudutan gantry.

Data yang di peroleh peneliti dari hasil pengujian perubahan gantry yang sudah dalam bentuk tabel, dilakukan pengolahan data menggunakan program SPSS 16. Pengujian menggunakan uji korelasi Pearson apabila data berdistribusi normal dan uji Range Spearman apabila data tidak berdistribusi normal. Pengujian SPSS ini digunakan untuk melihat apakah ada pengaruh dari perubahan variasi sudut gantry terhadap noise yang dihasilkan. Hasil output pengolahan SPSS peneliti sajikan dalam bentuk tabel dan pembahasan dari data yang dihasilkan.

\section{Hasil dan Pembahasan}

1. Hasil pengukuran pengaruh perubahan sudut gantry terhadap nilai CT Number dan Standard Deviasi.

Pengukuran dilihat dari nilai rata-rata $C T$ Number dan Standard Deviasi yang dihasilkan pada ROI pusat masing masing citra dari perubahan sudut gantry, sebagaimana ditunjukkan pada tabel berikut :

Tabel 1. Nilai CT Number dan Standard Deviasi

\begin{tabular}{|c|c|c|}
\hline $\begin{array}{c}\text { Sudut } \\
\text { Gantry }\end{array}$ & $\begin{array}{c}\text { Rata-rata Nilai } \text { ROI } \\
(\text { CT Number })\end{array}$ & $\begin{array}{c}\text { Rata-rata } \\
\text { Standard Deviasi } \\
(S D)\end{array}$ \\
\hline $0^{0}$ & $-1,43$ & 2,36 \\
\hline$-5^{0}$ & $-1,48$ & 2,35 \\
\hline$-10^{0}$ & $-1,47$ & 2,3 \\
\hline$-15^{0}$ & $-1,58$ & 2,33 \\
\hline$-20^{0}$ & $-1,62$ & 2,42 \\
\hline$-25^{0}$ & $-1,68$ & 2,57 \\
\hline$-30^{0}$ & $-1,7$ & 2,62 \\
\hline
\end{tabular}

Perubahan sudut gantry mengakibatkan terjadinya peningkatan noise yang dilihat dari fluktuasi nilai CT Number dan Standard Deviasi. Nilai CT Number dan Standard Deviasi yang dihasilkan pada sudut gantry $0^{0}$ dianggap sebagai nilai dasar untuk mengevaluasi ada tidaknya peningkatan nilai CT Number dan Standard Deviasi pada setiap perubuhan sudut gantry. Nilai $C T$ Number yang dihasilkan mengalami peningkatan pada sudut $-5^{0},-15^{0},-20^{0},-25^{0}$, dan $-30^{\circ}$. Sedangkan pada sudut gantry $-10^{0}$ terjadi penurunan dibandingkan nilai CT Number pada sudut gantry $5^{0}$. Nilai Standard Deviasi yang dihasilkan terjadi peningkatan pada sudut $-20^{\circ},-25^{0}$, dan $-30^{0}$, sedangkan pada sudut $-5^{0},-10^{0}$, dan $-15^{0}$ terjadi penurunan dibandingkan nilai pada sudut gantry $0^{0}$.

Hasil nilai pengukuran selanjutnya dilakukan uji normalitas data terlebih dahulu untuk mengetahui distribusi data yang akan dilakukan pengujian statistik, sebagaimana ditunjukkan pada tabel berikut:

Tabel 2. Tabel Hasil Uji Statistik Normalitas Data

\begin{tabular}{|c|c|c|}
\hline Variabel & p-value & Keterangan \\
\hline Perubahan sudut gantry & 0,949 & $\begin{array}{c}\text { Berdistribusi } \\
\text { normal }\end{array}$ \\
\hline Standar Deviasi & 0,125 & $\begin{array}{c}\text { Berdistribusi } \\
\text { normal }\end{array}$ \\
\hline
\end{tabular}




\begin{tabular}{ccc}
\hline Nilai CT Number & 0,434 & $\begin{array}{c}\text { Berdistribusi } \\
\text { normal }\end{array}$ \\
\hline
\end{tabular}

Hasil uji normalitas data perubahan sudut gantry dengan nilai p-value. 0,949 ( $p$-value $>0,05)$, nilai CT Number dengan nilai $p$-value 0,434 ( $p$ value $>0,05)$ dan Standard Deviasi dengan nilai $p$ value $0,125 \quad(p$-value $>0,05) \quad$ sehingga data berdistribusi normal.

Uji korelasi Pearson dilakukan untuk mengetahui hubungan antara perubahan sudut gantry dengan noise dilihat dari nilai CT Number dan Standard Deviasi, sebagaimana ditunjukkan pada tabel berikut :

Tabel 3. Uji Korelasi Pearson antara perubahan sudut gantry dengan nilai CT Number dan Standard Deviasi.

\begin{tabular}{lcc}
\hline \multicolumn{1}{c}{ Variabel } & p-value & Keterangan \\
\hline $\begin{array}{l}\text { Perubahan sudut } \\
\text { gantry dengan } C T\end{array}$ & 0,000 & Ada korelasi \\
Number & & \\
\end{tabular}

Perubahan sudut

0,021

Ada korelasi

gantry dengan

Standard Deviasi

Tabel di atas menunjukkan bahwa hasil Uji Korelasi antara perubahan sudut gantry dengan nilai $C T$ Number dengan nilai $p$-value 0,000 ( $p$ value $<0,05)$, sedangkan pada perubahan sudut gantry dengan Standard Deviasi dengan nilai $p$ value 0,021 ( $p$-value $<0,05)$. Ho ditolak sehingga ada korelasi yang signifikan antara perubahan sudut gantry dengan nilai $C T$ Number dan Standard Deviasi.

2. Perubahan sudut gantry terhadap nilai $C T$ Number dan Standard Deviasi yang masih sesuai dengan standar peraturan BAPETEN.

Uji CT Number (HU)

Perhitungan dilakukan dengan menghitung ratarata nilai $C T$ Number setiap citra dengan penempatan ROI pada pusat. Standar nilai rata-rata $C T$ Number yang dihasilkan menurut BAPETEN No. 2 tahun $2018-4 \leq$ $C T$ Number $\leq 4$. Berikut ini hasil perhitungan $C T$ Number pada setiap perubahan sudut gantry:

Tabel 4. Hasil Nilai CT Number ROI pusat

\begin{tabular}{|c|c|c|c|}
\hline $\begin{array}{c}\text { Sudut } \\
\text { Gantry }\end{array}$ & $\begin{array}{c}\text { Rata-rata Nilai } \\
\text { CT Number }\end{array}$ & \multirow{2}{*}{ Kriteria } & Kesimpulan \\
\hline $0^{0}$ & $-1,43$ & \multirow{2}{*}{ Nilai } & Sesuai standar \\
\hline$-5^{0}$ & $-1,48$ & $\mathrm{CT} \leq 4$ & Sesuai standar \\
\hline$-10^{0}$ & $-1,47$ & & Sesuai standar \\
\hline$-15^{0}$ & $-1,58$ & & Sesuai standar \\
\hline$-20^{0}$ & $-1,62$ & & Sesuai standar \\
\hline$-25^{0}$ & $-1,68$ & & Sesuai standar \\
\hline$-30^{0}$ & $-1,7$ & & Sesuai standar \\
\hline
\end{tabular}

Nilai CT Number yang dihasilkan pada semua perubahan sudut gantry sesuai dengan standar BAPETEN No.2 tahun 2018 (-4 $\leq$ CT Number $\leq 4)$.

Uji Uniformity
Perhitungan dilakukan dengan mengukur nilai CT Number pada masing masing citra. Nilai CT Number di dapat dari penempatan $R O I$ sebesar $2 \mathrm{~cm}$ pada pusat, jam 3, jam 6, jam 9, dan jam 12 dari nilai rata rata nilai tiap area. Perhitungan dilakukan dengan melihat selisih nilai $C T$ Number antara pusat dengan masing masing tepi penempatan $R O I$. Standar selisih rata-rata nilai $C T$ Number pusat dengan tepi adalah $\leq 2$ menurut peraturan BAPETEN No. 2 tahun 2018. Hasil perhitungannya, antara lain :

Tabel 5. Uniformity CT Number pada sudut gantry $0^{0}$

\begin{tabular}{|c|c|c|c|c|c|}
\hline $\begin{array}{l}\text { Area } \\
\text { Pengukuran }\end{array}$ & $\begin{array}{l}\text { Nilai } C T \\
\text { Number }\end{array}$ & \multicolumn{2}{|c|}{$\begin{array}{l}\text { Hasil Perhitungan } \\
\text { selisih (Pusat-Tepi) }\end{array}$} & Kriteria & Kesimpulan \\
\hline Pusat (A1) & $-1,43$ & & & $\Delta \mathrm{CT} \leq 2$ & Sesuai \\
\hline Jam 3 (A2) & $-2,3$ & $\overline{\mathrm{A} 1-\mathrm{A} 2}$ & 0,87 & $\begin{array}{l}\Delta \mathrm{CT} \text { : nilai } \\
\text { maksimum }\end{array}$ & \\
\hline Jam 6 (A3) & $-2,3$ & A1-A3 & 0,87 & $\begin{array}{l}\text { selisih } R O I \\
\text { rata-rata di }\end{array}$ & \\
\hline Jam 9 (A4) & $-2,28$ & $\overline{\mathrm{A} 1-\mathrm{A} 4}$ & 0,85 & $\begin{array}{l}\text { pusat } \\
\text { dengan } \\
\text { ROI rata- }\end{array}$ & \\
\hline Jam 12(A5) & $-1,85$ & $\overline{\mathrm{A} 1-\mathrm{A} 5}$ & 0,41 & $\begin{array}{l}\text { rata di } \\
\text { tepitepinya. }\end{array}$ & \\
\hline
\end{tabular}

Tabel 6. Uniformity CT Number pada sudut gantry $-5^{0}$

\begin{tabular}{|c|c|c|c|c|c|}
\hline $\begin{array}{l}\text { Area } \\
\text { Pengukuran }\end{array}$ & $\begin{array}{l}\text { Nilai } C T \\
\text { Number }\end{array}$ & \multicolumn{2}{|c|}{$\begin{array}{l}\text { Hasil } \\
\text { Perhitungan } \\
\text { selisih } \\
\text { (Pusat-Tepi) }\end{array}$} & Kriteria & Kesimpulan \\
\hline Pusat (A1) & $-1,48$ & & & $\begin{array}{l}\Delta \mathrm{CT} \leq 2 \mathrm{CT} \\
\Delta \mathrm{CT} \text { : nilai }\end{array}$ & $\begin{array}{l}\text { Sesuai } \\
\text { standar }\end{array}$ \\
\hline Jam 3 (A2) & $-2,12$ & $\begin{array}{l}\text { A1- } \\
\text { A2 }\end{array}$ & 0,64 & $\begin{array}{l}\text { dari } \\
\text { selisih ROI }\end{array}$ & \\
\hline Jam 6 (A3) & $-1,72$ & $\begin{array}{l}\text { A1- } \\
\text { A3 }\end{array}$ & 0,24 & $\begin{array}{l}\text { rata-rata di } \\
\text { pusat } \\
\text { dengan } R O I\end{array}$ & \\
\hline Jam 9 (A4) & $-2,26$ & $\begin{array}{l}\text { A1- } \\
\text { A4 }\end{array}$ & 0,78 & $\begin{array}{l}\text { rata-rata di } \\
\text { tepitepinya. }\end{array}$ & \\
\hline Jam 12 (A5) & $-2,12$ & $\begin{array}{l}\text { A1- } \\
\text { A5 }\end{array}$ & 0,64 & & \\
\hline
\end{tabular}

Tabel 7. Uniformity CT Number pada sudut gantry $-10^{0}$

\begin{tabular}{|c|c|c|c|c|c|}
\hline $\begin{array}{l}\text { Area } \\
\text { Pengukuran }\end{array}$ & $\begin{array}{l}\text { Nilai } C T \\
\text { Number }\end{array}$ & \multicolumn{2}{|c|}{$\begin{array}{l}\text { Hasil } \\
\text { Perhitungan } \\
\text { selisih } \\
\text { (Pusat-Tepi) }\end{array}$} & Kriteria & Kesimpulan \\
\hline Pusat (A1) & $-1,47$ & & & \multirow{5}{*}{$\begin{array}{l}\Delta \mathrm{CT} \leq 2 \mathrm{CT} \\
\Delta \mathrm{CT} \text { : nilai } \\
\text { maksimum } \\
\text { dari } \\
\text { selisih } R O I \\
\text { rata-rata di } \\
\text { pusat } \\
\text { dengan } R O I \\
\text { rata-rata di } \\
\text { tepitepinya. }\end{array}$} & \multirow[t]{5}{*}{$\begin{array}{l}\text { Sesuai } \\
\text { standar }\end{array}$} \\
\hline Jam $3(\mathrm{~A} 2)$ & $-2,18$ & $\begin{array}{l}\text { A1- } \\
\text { A2 }\end{array}$ & 0,71 & & \\
\hline Jam 6 (A3) & $-1,95$ & $\begin{array}{l}\text { A1- } \\
\text { A3 }\end{array}$ & 0,48 & & \\
\hline Jam 9 (A4) & $-1,97$ & $\begin{array}{l}\text { A1- } \\
\text { A4 }\end{array}$ & 0,5 & & \\
\hline Jam 12 (A5) & $-1,3$ & $\begin{array}{l}\text { A1- } \\
\text { A5 }\end{array}$ & 0,17 & & \\
\hline
\end{tabular}

Tabel 8. Uniformity CT Number pada sudut gantry $-15^{0}$

\begin{tabular}{|c|c|c|c|c|c|}
\hline $\begin{array}{l}\text { Area } \\
\text { Pengukuran }\end{array}$ & $\begin{array}{l}\text { Nilai } C T \\
\text { Number }\end{array}$ & \multicolumn{2}{|c|}{$\begin{array}{l}\text { Hasil Perhitungan } \\
\text { selisih } \\
\text { (Pusat-Tepi) }\end{array}$} & Kriteria & Kesimpulan \\
\hline Pusat (A1) & $-1,58$ & & & $\Delta \mathrm{CT} \leq 2$ & $\begin{array}{l}\text { Sesuai } \\
\text { standar }\end{array}$ \\
\hline Jam 3 (A2) & $-2,42$ & A1-A2 & 0,84 & $\begin{array}{l}\Delta \mathrm{CT} \text { : nilai } \\
\text { maksimum }\end{array}$ & \\
\hline Jam 6 (A3) & -2.07 & A1-A3 & 0,49 & rata-rata di & \\
\hline Jam 9 (A4) & $-1,98$ & A1-A4 & 0,4 & $\begin{array}{l}\text { pusat } \\
\text { dengan } R O I \\
\text { rata-rata di }\end{array}$ & \\
\hline Jam 12 (A5) & $-1,85$ & A1-A5 & 0,27 & tepitepinya. & \\
\hline
\end{tabular}


Tabel 9. Uniformity CT Number pada sudut gantry $-20^{\circ}$

\begin{tabular}{|c|c|c|c|c|c|}
\hline $\begin{array}{l}\text { Area } \\
\text { Pengukuran }\end{array}$ & $\begin{array}{l}\text { Nilai } C T \\
\text { Number }\end{array}$ & \multicolumn{2}{|c|}{$\begin{array}{l}\text { Hasil Perhitungan } \\
\text { selisih } \\
\text { (Pusat-Tepi) }\end{array}$} & Kriteria & Kesimpulan \\
\hline Pusat (A1) & $-1,62$ & & & $\begin{array}{l}\Delta \mathrm{CT} \leq 2 \\
\mathrm{CT}\end{array}$ & $\begin{array}{l}\text { Sesuai } \\
\text { standar }\end{array}$ \\
\hline $\operatorname{Jam} 3(\mathrm{~A} 2)$ & $-2,38$ & A1-A2 & 0,76 & $\begin{array}{l}\Delta \mathrm{CT} \text { : nilai } \\
\text { maksimum } \\
\text { dari }\end{array}$ & \\
\hline $\operatorname{Jam} 6(\mathrm{~A} 3)$ & $-2,27$ & A1-A3 & 0,65 & $\begin{array}{l}\text { selisih } R O I \\
\text { rata-rata di } \\
\text { pusat }\end{array}$ & \\
\hline Jam 9 (A4) & $-2,32$ & A1-A4 & 0,7 & dengan $\mathrm{ROI}$ & \\
\hline Jam 12 (A5) & $-1,76$ & A1-A5 & 0,14 & tepitepinya. & \\
\hline
\end{tabular}

Tabel 10 Uniformity CT Number pada sudut gantry $-25^{0}$

\begin{tabular}{|l|l|l|l|l|l|}
\hline $\begin{array}{l}\text { Area } \\
\text { Pengukuran }\end{array}$ & $\begin{array}{l}\text { Nilai } C T \\
\text { Number }\end{array}$ & $\begin{array}{l}\text { Hasil Perhitungan } \\
\text { selisih } \\
\text { (Pusat-Tepi) }\end{array}$ & Kriteria & Kesimpulan \\
\hline Pusat (A1) & $-1,68$ & \multicolumn{2}{|l|}{} & $\begin{array}{l}\Delta \mathrm{CT} \leq 2 \\
\text { CT }\end{array}$ & $\begin{array}{l}\text { Sesuai } \\
\text { standar }\end{array}$ \\
\hline Jam 3 (A2) & $-2,2$ & A1-A2 & 0,52 & $\begin{array}{l}\Delta \mathrm{CT} \text { : nilai } \\
\text { maksimum } \\
\text { dari } \\
\text { selisih } \text { ROI } \\
\text { rata-rata di } \\
\text { pusat } \\
\text { dengan } \text { ROI } \\
\text { rata-rata di } \\
\text { tepitepinya. }\end{array}$ & \\
\hline Jam 6 (A3) & $-1,98$ & A1-A3 & 0,3 & \\
\hline Jam 9 (A4) & $-2,2$ & A1-A4 & 0,52 & \\
\hline Jam 12 (A5) & $-1,48$ & A1-A5 & 0,2 & \\
\hline
\end{tabular}

Tabel 11 Uniformity CT Number pada sudut gantry $-30^{\circ}$

\begin{tabular}{|c|c|c|c|c|c|}
\hline $\begin{array}{l}\text { Area } \\
\text { Pengukuran }\end{array}$ & $\begin{array}{l}\text { Nilai } C T \\
\text { Number }\end{array}$ & \multicolumn{2}{|c|}{$\begin{array}{l}\text { Hasil Perhitungan } \\
\text { selisih } \\
\text { (Pusat-Tepi) }\end{array}$} & Kriteria & Kesimpulan \\
\hline $\begin{array}{l}\text { Pusat (A1) } \\
\text { Pas }\end{array}$ & $-1,7$ & & & & $\begin{array}{l}\text { Sesuai } \\
\text { standar }\end{array}$ \\
\hline Jam 3 (A2) & $-1,98$ & A1-A2 & 0,28 & & \\
\hline Jam 6 (A3) & $-1,5$ & A1-A3 & 0,2 & $\begin{array}{l}\text { rata-rata di } \\
\text { pusat }\end{array}$ & \\
\hline Jam 9 (A4) & $-1,68$ & A1-A4 & 0,02 & $\begin{array}{l}\text { dengan } R O I \\
\text { rata-rata di } \\
\text { tepitepinya. }\end{array}$ & \\
\hline Jam 12 (A5) & $-2,5$ & A1-A5 & 0,5 & & \\
\hline
\end{tabular}

\section{Uji Keseragaman Noise}

Perhitungan dilakukan dengan menghitung nilai rata-rata Standar Deviasi pada masing masing citra. Nilai Standard Deviasi di dapat dari penempatan ROI sebesar $2 \mathrm{~cm}$ pada pusat, jam 3, jam 6, jam 9, dan jam 12. Perhitungan dilakukan dengan melihat selisih nilai Standard Deviasi antara pusat dengan masing masing tepi penempatan ROI. Standar selisih rata-rata nilai Standard Deviasi pusat dengan tepi adalah $\leq 2$ menurut peraturan BAPETEN No. 2 tahun 2018. Hasil perhitungannya, antara lain :

Tabel 12. Uji Keseragaman Noise pada sudut gantry $0^{0}$

\begin{tabular}{|l|l|l|l|l|l|}
\hline $\begin{array}{l}\text { Area } \\
\text { Pengukuran }\end{array}$ & $\begin{array}{l}\text { Nilai } \\
\text { Standard } \\
\text { Deviasi }\end{array}$ & $\begin{array}{l}\text { Hasil Perhitungan } \\
\text { Selisih } \\
\text { (Pusat-Tepi) }\end{array}$ & Kriteria & Kesimpulan \\
\hline Pusat (A1) & 2,36 & \multicolumn{1}{|l|}{} & $\begin{array}{l}\Delta \text { SD } \leq 2 \\
\text { CT } \\
\Delta \text { SD : } \\
\text { selisih } \\
\text { standar } \\
\text { deviasi } \\
\text { (SD) ROI }\end{array}$ & $\begin{array}{l}\text { Sesuai } \\
\text { standar }\end{array}$ \\
\hline Jam 3 (A2) & 1,85 & A1-A2 & 0,51 & \\
\hline Jam 6 (A3) & 1,9 & A1-A3 & 0,46 & & \\
\hline
\end{tabular}

\begin{tabular}{|l|l|l|l|l|l|}
\hline Jam 9 (A4) & 1,93 & A1-A4 & 0,43 & $\begin{array}{l}\text { maksimum } \\
\text { dengan SD } \\
\text { ROI } \\
\text { minimum }\end{array}$ & \\
\cline { 1 - 4 } $\begin{array}{l}\text { Jam 12 } \\
\text { (A5) }\end{array}$ & 2 & A1-A5 & 0,36 & \\
\hline
\end{tabular}

Tabel 13. Uji Keseragaman Noise pada sudut gantry $-5^{0}$.

\begin{tabular}{|c|c|c|c|c|c|}
\hline $\begin{array}{l}\text { Area } \\
\text { Pengukuran }\end{array}$ & $\begin{array}{l}\text { Nilai } \\
\text { Standard } \\
\text { Deviasi }\end{array}$ & \multicolumn{2}{|c|}{$\begin{array}{l}\text { Hasil Perhitungan } \\
\text { Selisih } \\
\text { (Pusat-Tepi) }\end{array}$} & Kriteria & Kesimpulan \\
\hline Pusat (A1) & 2,35 & & & \multirow{5}{*}{$\begin{array}{l}\Delta \mathrm{SD} \leq 2 \\
\mathrm{CT} \\
\Delta \mathrm{SD}: \\
\text { selisih } \\
\text { standar } \\
\text { deviasi } \\
\text { (SD) } R O I \\
\text { maksimum } \\
\text { dengan SD } \\
R O I \\
\text { minimum }\end{array}$} & \multirow[t]{5}{*}{$\begin{array}{l}\text { Sesuai } \\
\text { standar }\end{array}$} \\
\hline Jam 3 (A2) & 1,97 & A1-A2 & 0,38 & & \\
\hline Jam 6 (A3) & 1,96 & A1-A3 & 0,39 & & \\
\hline Jam 9 (A4) & 1,93 & A1-A4 & 0,42 & & \\
\hline $\begin{array}{l}\text { Jam } 12 \\
\text { (A5) }\end{array}$ & 2 & A1-A5 & 0,35 & & \\
\hline
\end{tabular}

Tabel 14 Uji Keseragaman Noise pada sudut gantry $-10^{0}$

\begin{tabular}{|c|c|c|c|c|c|}
\hline $\begin{array}{l}\text { Area } \\
\text { Pengukuran }\end{array}$ & $\begin{array}{l}\text { Nilai } \\
\text { Standard } \\
\text { Deviasi }\end{array}$ & \multicolumn{2}{|c|}{$\begin{array}{l}\text { Hasil Perhitungan } \\
\text { Selisih } \\
\text { (Pusat-Tepi) }\end{array}$} & Kriteria & Kesimpulan \\
\hline Pusat (A1) & 2,3 & & & $\begin{array}{l}\Delta \mathrm{SD} \leq 2 \\
\mathrm{CT}\end{array}$ & $\begin{array}{l}\text { Sesuai } \\
\text { standard }\end{array}$ \\
\hline Jam 3 (A2) & 1,88 & A1-A2 & 0,42 & $\begin{array}{l}\text { selisih } \\
\text { standar } \\
\text { deviasi }\end{array}$ & \\
\hline Jam 6 (A3) & 1,9 & $\overline{\mathrm{A} 1-\mathrm{A} 3}$ & 0,4 & $\begin{array}{l}\text { eviasi } \\
\text { (SD) ROI } \\
\text { maksimum }\end{array}$ & \\
\hline Jam 9 (A4) & 2,03 & $\overline{\mathrm{A} 1-\mathrm{A} 4}$ & 0,27 & $\begin{array}{l}\text { dengan SD } \\
R O I \\
\text { minimum }\end{array}$ & \\
\hline $\begin{array}{l}\text { Jam } 12 \\
\text { (A5) }\end{array}$ & 2,22 & A1-A5 & 0,08 & & \\
\hline
\end{tabular}

Tabel 15 Uji Keseragaman Noise pada sudut gantry $-15^{0}$

\begin{tabular}{|c|c|c|c|c|c|}
\hline $\begin{array}{l}\text { Area } \\
\text { Pengukuran }\end{array}$ & $\begin{array}{l}\text { Nilai } \\
\text { Standard } \\
\text { Deviasi }\end{array}$ & \multicolumn{2}{|c|}{$\begin{array}{l}\text { Hasil Perhitungan } \\
\text { Selisih } \\
\text { (Pusat-Tepi) }\end{array}$} & Kriteria & Kesimpulan \\
\hline Pusat (A1) & 2,33 & & & $\begin{array}{l}\Delta \mathrm{SD} \leq 2 \\
\mathrm{CT}\end{array}$ & $\begin{array}{l}\begin{array}{l}\text { Sesuai } \\
\text { standard }\end{array}\end{array}$ \\
\hline Jam 3 (A2) & 1,98 & $\overline{A 1-A 2}$ & 0,35 & $\begin{array}{l}\Delta \mathrm{SD}: \\
\text { selisih } \\
\text { standar }\end{array}$ & \\
\hline Jam 6 (A3) & 1,95 & A1-A3 & 0,38 & $\begin{array}{l}\text { deviasi } \\
\text { (SD) } R O I \\
\text { maksimum }\end{array}$ & \\
\hline Jam 9 (A4) & 2,02 & A1-A4 & 0,31 & $\begin{array}{l}\text { dengan SD } \\
R O I \\
\text { minimum }\end{array}$ & \\
\hline $\begin{array}{l}\text { Jam } 12 \\
\text { (A5) }\end{array}$ & 2,07 & $\overline{\mathrm{A} 1-\mathrm{A} 5}$ & 0,26 & & \\
\hline
\end{tabular}

Tabel 16 Uji Keseragaman Noise pada sudut gantry $-20^{\circ}$

\begin{tabular}{|c|c|c|c|c|c|}
\hline $\begin{array}{l}\text { Area } \\
\text { Pengukuran }\end{array}$ & $\begin{array}{l}\text { Nilai } \\
\text { Standard } \\
\text { Deviasi } \\
\end{array}$ & \multicolumn{2}{|c|}{$\begin{array}{l}\text { Hasil Perhitungan } \\
\text { Selisih } \\
\text { (Pusat-Tepi) }\end{array}$} & Kriteria & Kesimpulan \\
\hline Pusat (A1) & 2,42 & & & $\begin{array}{l}\Delta \mathrm{SD} \leq 2 \\
\mathrm{CT}\end{array}$ & $\begin{array}{l}\text { Sesuai } \\
\text { standar }\end{array}$ \\
\hline Jam 3 (A2) & 1,92 & $\mathrm{~A} 1-\mathrm{A} 2$ & 0,5 & $\begin{array}{l}\Delta \mathrm{SD}: \\
\text { selisih } \\
\text { standar }\end{array}$ & \\
\hline Jam 6 (A3) & 1,95 & A1-A3 & 0,47 & $\begin{array}{l}\text { deviasi } \\
\text { (SD) ROI } \\
\text { maksimum }\end{array}$ & \\
\hline Jam 9 (A4) & 1,98 & A1-A4 & 0,44 & $\begin{array}{l}\text { dengan } \mathrm{SD} \\
R O I \\
\text { minimum }\end{array}$ & \\
\hline $\begin{array}{l}\text { Jam } 12 \\
\text { (A5) }\end{array}$ & 2,15 & A1-A5 & 0,27 & & \\
\hline
\end{tabular}

Tabel 17 Uji Keseragaman Noise pada sudut gantry $-25^{0}$

\begin{tabular}{|c|c|c|c|c|}
\hline $\begin{array}{l}\text { Area } \\
\text { Pengukuran }\end{array}$ & $\begin{array}{l}\text { Nilai } \\
\text { Standard } \\
\text { Deviasi }\end{array}$ & $\begin{array}{l}\text { Hasil Perhitungan } \\
\text { Selisih } \\
\text { (Pusat-Tepi) }\end{array}$ & Kriteria & Kesimpulan \\
\hline Pusat (A1) & 2,57 & & \multirow{2}{*}{$\begin{array}{l}\Delta \mathrm{SD} \leq 2 \\
\mathrm{CT} \\
\Delta \mathrm{SD}:\end{array}$} & \multirow[t]{2}{*}{$\begin{array}{l}\text { Sesuai } \\
\text { standar }\end{array}$} \\
\hline Jam 3 (A2) & 1,92 & A1-A2 & & \\
\hline
\end{tabular}




\begin{tabular}{|c|c|c|c|c|}
\hline Jam 6 (A3) & 2,03 & $\overline{\mathrm{A} 1-\mathrm{A} 3}$ & 0,54 & selisih \\
\hline Jam 9 (A4) & 2,03 & A1-A4 & 0,54 & $\begin{array}{l}\text { deviasi } \\
\text { (SD) } R O I \\
\text { maksimum }\end{array}$ \\
\hline $\begin{array}{l}\text { Jam } 12 \\
\text { (A5) }\end{array}$ & 2,23 & $\overline{\mathrm{A} 1-\mathrm{A} 5}$ & 0,34 & $\begin{array}{l}\text { dengan SD } \\
R O I \\
\text { minimum }\end{array}$ \\
\hline
\end{tabular}

Tabel 18 Uji Keseragaman Noise pada sudut gantry $-30^{0}$

\begin{tabular}{|c|c|c|c|c|c|}
\hline $\begin{array}{l}\text { Area } \\
\text { Pengukuran }\end{array}$ & $\begin{array}{l}\text { Nilai } \\
\text { Standard } \\
\text { Deviasi }\end{array}$ & \multicolumn{2}{|c|}{$\begin{array}{l}\text { Hasil Perhitungan } \\
\text { Selisih } \\
\text { (Pusat-Tepi) }\end{array}$} & Kriteria & Kesimpulan \\
\hline Pusat (A1) & 2,62 & & & \multirow{5}{*}{$\begin{array}{l}\Delta \mathrm{SD} \leq 2 \\
\mathrm{CT} \\
\Delta \mathrm{SD}: \\
\text { selisih } \\
\text { standar } \\
\text { deviasi } \\
\text { (SD) } R O I \\
\text { maksimum } \\
\text { dengan SD } \\
R O I \\
\text { minimum }\end{array}$} & \multirow[t]{5}{*}{$\begin{array}{l}\text { Sesuai } \\
\text { standar }\end{array}$} \\
\hline Jam 3 (A2) & 2,05 & A1-A2 & 0,57 & & \\
\hline Jam 6 (A3) & 2,17 & A1-A3 & 0,45 & & \\
\hline Jam 9 (A4) & 2,32 & A1-A4 & 0,3 & & \\
\hline $\begin{array}{l}\text { Jam } 12 \\
\text { (A5) }\end{array}$ & 2,12 & A1-A5 & 0,5 & & \\
\hline
\end{tabular}

1. Pengaruh perubahan sudut gantry terhadap noise pada pemeriksaan CT Scan dengan teknik sequence.

Hasil penelitian untuk menilai pengaruh perubahan sudut gantry terhadap noise pada pemeriksaan CT Scan dengan teknik sequence, terdapat hubungan yang signifikan antara perubahan sudut gantry dengan nilai $C T$ Number pada uji korelasi pearson dengan nilai p-value 0,000 . Terdapat hubungan yang signifikan antara perubahan sudut gantry dengan nilai Standard Deviasi nilai $p$-value 0,021 . Peningkatan noise ditunjukkan oleh fluktuasi nilai $C T$ Number dan Standard Deviasi yang dihasilkan dari penempatan ROI di pusat pada masing-masing citra yang dihasilkan setiap perubahan sudut gantry. Nilai ratarata $C T$ Number pada sudut gantry $0^{0}(-1,43), 5^{0}(-$ $1,48), 10^{0}(-1,47), 15^{0}(-1,58), 20^{\circ}(-1,62), 25^{0}(-1,68)$, $30^{\circ}(-1,7)$. Nilai rata-rata Standard Deviasi pada sudut gantry $0^{0}(2,36), 5^{0}(2,35), 10^{0}(2,3), 15^{0}(2,33)$, $20^{\circ}(2,42), 25^{0}(2,57), 30^{\circ}(2,62)$.

Fluktuasi noise disebabkan karena perubahan tebal objek area scanning dari perubahan sudut gantry. Semakin besar perubahan sudut gantry, maka semakin besar pula tebal objek area scanning. Perubahan sudut gantry mengakibatkan area scanning barubah dari bidang lingkaran menjadi bidang elips. Ini dapat dilihat dari citra yang dihasilkan dan pengukuran pada citra pada bidang horisontal. Pada sudut gantry $0^{0}$ tebal objek 18,86 $\mathrm{cm} ; 5^{0}(18,83 \mathrm{~cm}), 10^{0}(18,91 \mathrm{~cm}), 15^{0}(19,13 \mathrm{~cm})$, $20^{\circ}(19,52 \mathrm{~cm}), 25^{\circ}(20,05 \mathrm{~cm})$ dan $30^{\circ}(20,83)$. Menurut Seeram (2009), noise di pengaruhi oleh tebal objek dan fluktuasi sinar-X atau jumlah foton sinar-X yang terdeteksi oleh detektor. Intensitas radiasi sinar-X setelah menembus objek berbanding terbalik dengan tebal bahan. Semakin kecil intensitas sinar-X maka semakin tinggi noise yang dihasilkan.

2. Perubahan sudut gantry yang menghasilkan nilai Standar Deviasi CT Number yang masih sesuai dengan peraturan BAPETEN.

Menurut Jaengsri (2004) uji CT Number dilakukan untuk melihat akurasi nilai $C T$ Number pada pemeriksaan $C T$ Scan. Berdasarkan uji $C T$ Number yang digunakan untuk melihat pengaruh perubahan sudut gantry pada nilai rata-rata $C T$ Number yang dihasilkan dengan penempatan $R O I$ pusat pada setiap citra yang dihasilkan, maka dapat disimpulkan bahwa nilai $C T$ Number yang dihasilkan masih sesuai dengan standar BAPETEN No. 2 tahun 2018. Nilai rata-rata CT Number pada sudut gantry $0^{0}$ adalah $-1,43 ;-5^{0}(-1,48) ;-10^{0}(-1,47)$; $-15^{0}(-1,58) ; \quad-20^{0}(-1,62) ; \quad-25^{0}(-1,68) ; \quad-30^{0}(-1,7)$. Dimana standar nilai $C T$ Number menurut BAPETEN adalah $-4 \leq$ CT Number $\leq 4$.

Uji Uniformity yang digunakan untuk menilai cupping artefak dilihat dari data image yang dihasilkan (Seeram, 2009). Uji Uniformity dilakukan dengan melihat selisih nilai $C T$ Number pada pusat dengan masing-masing tepi yang ditempatkan pada jam 3, jam 6, jam 9, dan jam 12. Selisih nilai ratarata $C T$ Number pada perubahan sudut $0^{0},-5^{0},-10^{0}$, $15^{0},-20^{0},-25^{0}$, dan $-30^{0}$, masih sesuai dengan standard BAPETEN No. 2 tahun 2018, dimana selisih rata-rata nilai $C T$ Number pusat dengan tepi adalah $\leq 2$.

Uji keseragaman noise dilakukan untuk menilai Standard Deviasi dari nilai-nilai pixel yang terdapat dalam matriks dari sebuah citra CT Scan (Seeram, 2009). Standar kriteria menurut BAPETEN No. 2 tahun 2009 bahwa selisih nilai Standard Deviasi $R O I$ pusat dengan ROI tepi adalah $\leq 2$. Nilai selisih Standard Deviasi yang dihasilkan pada perubahan sudut $0^{0},-5^{0},-10^{0},-15^{0},-20^{0},-25^{0}$, dan $-30^{0}$ masih sesuai dengan standard, dimana selisih rata-rata nilai Standar Deviasi dibawah angka 2.

Kelemahan Penelitian:

Kelemahan penelitian yang terdapat pada penyusunan Karya Tulis Ilmiah ini yaitu pada material yang dipakai oleh peneliti didalam pengambilan data penelitian, antara lain peneliti menggunakan water phantom buatan untuk menilai image noise dari citra yang dihasilkan pada setiap perubahan sudut gantry yang dilakukan. Peneliti tidak menggunakan dosimeter yang diletakkan pada organ untuk mengetahui besar noise yang diterima oleh dosimeter.

Penelitian yang dilakukan oleh Nikupaavo dkk (2015) menggunakan material anthromorphic phantom ATOM model 702-D (CIRS) dan RANDO (phantom laboratory) yang digunakan untuk menilai dosis dengan MOSFET dosimeter dan image noise. Scanning menggunakan teknik helical dengan scan parameter yang digunakan adalah parameter kepala.

Penelitian yang dilakukan oleh Hoppe dkk. (2013) bertujuan untuk menilai dosis dan image noise yang dihasilkan. MOSFET dosimeter digunakan untuk menilai dosis yang diterima. Metode pengambilan data dilakukan dengan cara eksperimental dan simulation studies. Lungman RANDO phantom dan MOSFET dosimeter digunakan pada metode ekperimental. Sedangkan pada simulation studies menggunakan 
Monte Carlo Simulation yang diolah dengan software SPEC78 dalam menilai dosis dan image noise.

Nilai CT Number dan Standard Deviasi seharusnya semakin naik dengan bertambahnya perubahan sudut gantry. Namun terdapat anomali data pada nilai $C T$ Number pada sudut $10^{\circ}$ dan Standard Deviasi pada sudut $5^{0}, 10^{\circ}$ dan $15^{\circ}$. Penurunan nilai dapat terjadi karena data yang diambil berupa sample penempatan ROI pada citra yang dihasilkan. Dapat juga terjadi karena permukaan bahan acrilic pada water phantom kurang rata dan bentuk tabung yang tidak berbentuk lingkaran sempurna.

\section{Simpulan}

1. Terjadi peningkatan noise yang ditunjukkan oleh fluktuasi nilai CT Number dan Standard Deviasi yang dihasilkan dari penempatan ROI di pusat pada masing-masing citra yang dihasilkan setiap perubahan sudut gantry. Nilai rata-rata CT Number pada sudut gantry $0^{0}(-1,43),-5^{0}(-1,48),-10^{0}(-1,47)$, $15^{0}(-1,58),-20^{0}(-1,62),-25^{0}(-1,68),-30^{0}(-1,7)$. Nilai rata-rata Standard Deviasi pada sudut gantry $0^{0}(2,36),-5^{0}(2,35),-10^{0}(2,3),-15^{0}(2,33),-20^{0}(2,42)$, $-25^{\circ}(2,57),-30^{0}(2,62)$. Terdapat hubungan yang signifikan pada perubahan sudut gantry dengan nilai CT Number dan nilai Standard Deviasi.

2. Hasil Uji CT Number, Uniformity, dan Keseragaman noise yang digunakan untuk menilai fluktuasi $C T$ Number dan Standard Deviasi akibat perubahan sudut gantry sesuai dengan standard BAPETEN No. 2 Tahun 2018 pada semua perubahan sudut gantry $0^{0},-5^{0},-10^{0},-15^{0},-20^{0},-25^{0}$ dan $-30^{0}$.

\section{Daftar Pustaka}

Hoppe M.E., Gandhi D., Stevens G.M., Foley W.D., Schmidt T.G., 2013, The Effects Of Gantry Tilt On Breast Dose And Image Noise In Cardiac $C T$, Department of Biomedical Engineering, Marquette University, Milwaukee, Wisconsin.

Jaengsri Nuttawan, 2004, CT Protocol, Radiology Departement Of Takshin Hospital, Bangkok.

Kurniawan A.N. dan Soesanti I., 2010, Evaluasi Nilai Noise Sebelum Dan Sesudah Kalibrasi Sebagai Salah Satu Wujud Kinerja Pesawat CT-Scan, ISSN : 0216 - 7565Forum Teknik Vol. 33, No. 3.

Mas'uul A.R. dan Susanto H., 2014, Uji Kesesuaian Ct Number Pada Pesawat Ct Scan Multislice Di Unit Radiologi Rumah Sakit Islam Yogyakarta PDHI, Youngster Physics Journal ISSN : 2302 7371 Vol. 3, No. 44, Hal 335- 340.

Nikupaavo U., Kaasalainen T., Reijonen V., Ahonen S.M., Kortesinemi M., 2015, Lens Dose in Head CT: Comparison of Different Optimazation Methods With Anthropomorphic Phantoms, AJR;204:117-123.
Peraturan Badan Pengawas Tenaga Nuklir Republik Indonesia Nomor 2 Tahun 2018, Uji Kesesuaian Pesawat Sinar-X Radiologi Diagnostik dan Intervensional.

Seeram E., 2009, Computed Tomography: Physical Principles, Clinical Applications, and Quality Control, 3rd Edition, Westline Industrial Drive St. Louis, Missouri. 